\title{
UCHODŹSTWO PODCZAS I WOJNY ŚWIATOWEJ W MALARSTWIE I GRAFICE - CASUS ZACHODNICH PROWINCJI ROSJI ${ }^{1}$
}

\section{Piotr Szlanta}

http://orcid.org/0000-0002-6573-2304

Uniwersytet Warszawski

\author{
ABSTRACT \\ WAR REFUGEES OF THE WORLD WAR I IN PAINTINGS \\ AND DRAWINGS FROM THE WESTERN RUSSIAN PROVINCES
}

During the World War I millions of civilians all around Europe and the Near East were often forced to leave their homes unprepared and in desperate hope of finding safety and refuge in distant lands. From the very beginning of the war, refugees became the topic and subject for both propagandists and artists alike. For the purposes of this article, a selected number of examples of drawings and paintings, presenting perspectives of Latvian, Polish and Jewish subjects of the tsar, have been chosen. In the iconography, war refugees are generally presented as innocent and helpless victims of the conflict, and as a proof of the brutality and barbarity of the unfolding hostilities. The article also explores the way artists honed in on the depictions of crying women; troubled and helpless old men; small children snuggling up to their mothers and people contending with hunger, cold, fear, disease, uncertainty of the future and longing for lost homes as well as separated family members. Very often, the typical backgrounds for such scenes are ruins and burning buildings. The artists who depicted the war refugees' fate did not always share such dramatic experiences personally. However, they clearly acknowledged the fact that it played a huge role in forming the identity of the nations they belonged to.

Keywords: war refugees, World War I, iconography, Russia, Latvia, Poland, Jews.

Słowa kluczowe: uchodźstwo wojenne, pierwsza wojna światowa, ikonografia, Rosja, Łotwa, Polska, Żydzi.

${ }^{1}$ Artykuł powstał w wyniku badań zrealizowanych w ramach grantu Narodowego Centrum Nauki 2018/29/B/HS3/02075.

Adres do korespondencji: p.szlanta@uw.edu.pl 


\section{WPROWADZENIE}

I wojna światowa uchodzi powszechnie za przykład pierwszego w dziejach konfliktu o charakterze totalnym. Jej totalność polegała między innym na tym, że działaniami wojennymi - choć w różnym stopniu - zostały dotknięte wszystkie warstwy społeczne. Różne zjawiska wywoływane zwykle przez wojnę w latach 1914-1918 występowały w niespotykanych dotąd skali i natężeniu, co dotyczyło także i ruchów uchodźczych. Europę i Bliski Wschód w różnych kierunkach przemierzały wymuszone działaniami zbrojnymi milionowe fale migracji. W Rosji dla przykładu liczbę uchodźców w styczniu 1917 roku szacowano na $6 \mathrm{mln}$. W ciągu pół roku wzrosła ona do 7,42 $\mathrm{mln}^{2}$. Los uchodźców był przedmiotem intensywnych debat publicznych, które toczyły się na łamach prasy, w parlamentach, gabinetach rządowych czy na forum organizacji pomocowych.

Do tego fenomenu odnieśli się tak podczas samej wojny, jak i po jej zakończeniu także artyści. Celem niniejszego artkułu jest przedstawienie na wybranych przykładach doświadczenia migracji z okresu wojny światowej oddanego przez malarzy i grafików. Jakimi środkami wyrazu artyści starli się oddać dramatyczne losy wychodźców? Jakie tematy z życia uchodźców podejmowali? Na jakie aspekty ich doświadczenia zwracali szczególną uwagę? Czy zajmowali się tą tematyką jedynie twórcy osobiście dotknięci tym doświadczeniem? Czynili to z własnej potrzeby czy też instytucje państwa były zainteresowane utrwaleniem losu uchodźców w takiej formie? Fakt silnego oddziaływania obrazów na masowego odbiorcę doskonale znany był osobom odpowiedzialnym za wojenną propagandę, która w latach 1914-1918 odgrywała ogromną rolę $\mathrm{w}$ mobilizacji społeczeństwa do wytrwania w przedłużającej się i generującej coraz większe koszty ludzkie, finansowe i materialne wojnie. Dlatego w tworzonych na zamówienie państw walczących przekazach propagandowych istotne miejsce zajmował obraz w postaci zdjęcia, karykatury, rysunku na plakacie i w prasie czy w końcu filmu. Oddziaływał on bowiem znacznie silniej niż na przykład tekst na emocje odbiorcy, i to niezależnie od jego wykształcenia czy miejsca zajmowanego w strukturze społecznej ${ }^{3}$.

Ze względu na bogactwo materii źródłowej na potrzeby artykułu wybrano przypadki łotewski, polski i żydowski, czyli grup narodowościowo-religijnych zamieszkujących zachodnie gubernie wielonarodowego imperium Romanowów oraz dotkniętych masowym zjawiskiem uchodźstwa wojennego.

2 P. Gatre11, A Whole Empire Walking: Refugees in Russia during World War I, Bloomington 2011, s. 211. Patrz także: S. Peeling, Refugees (Russian Empire) [w:] 1914-1918-online: International Encyclopedia of the First World War, eds. U. Daniel, P. Gatrell, O. Janz, H. Jones, J. Keene, A. Kramer, B. Nasson, Berlin 2014, http://www.1914-1918-online.net/ [dostęp: 16 IV 2020 r.]; P. Gatre11, Refugees [w:] 1914-1918-online: International Encyclopedia...

${ }^{3}$ W. Molik, Propaganda w okresie I wojny światowej. Organizacja i rola mediów [w:] Kwestia polska w propagandzie w okresie pierwszej wojny światowej, red. W. Molik, T. Schra m m, D. S zy mc zak, Poznań 2018, s. 28-49; Bildpropaganda im Ersten Weltkrieg, Hrsg. R. Zühlke, Hamburg 2000; R. Jaw orski, Mutter - Liebchen - Heroinen. Propagandapostkarten aus den Ersten Welt-Krieg, KölnWeimar-Wien 2015. 


\section{PRZYPADEK ŁOTEWSKI}

Ziemie zamieszkane przez Łotyszy stały się areną działań wojennych latem 1915 roku. Wówczas to wojska niemieckie opanowały zachodnią i południowo-zachodnią część dzisiejszej Łotwy (pokrywająca się z grubsza z granicami ówczesnej guberni kurlandzkiej), dochodząc do przedmieść Rygi. Z liczbą 530 tys. mieszkańców ( $2 / 3$ z nich to byli Łotysze) Ryga stanowiła czwarte miasto Imperium Romanowów. Od początku wojny znajdowali się w niej uchodźcy z rejonów przygranicznych ${ }^{4}$. Co więcej, Ryga przez dwa lata pozostawała miastem frontowym. Samo przybliżanie się linii frontu wywołało falę migracji ludności cywilnej, wymuszoną także taktyką spalonej ziemi stosowną przez wycofującą się armię rosyjską. Łącznie około 800 tys. osób udało się na poniewierkę w głąb Rosji, szukając tam bezpiecznego azylu. Jak na kraj liczący 2,6 mln mieszkańców była to znaczna liczba. Sama Ryga znalazła się pod stałym ostrzałem artyleryjskim; z ewakuowanymi lub zamkniętymi zakładami przemysłowymi, zamkniętym portem i zaminowanymi wodami wokół niego niemal opustoszała ${ }^{5}$. Podobnie rzecz miała się z Dyneburgiem (Daugavpils). W marcu 1916 roku wojsko rosyjskie dało zgromadzonym wokół niego 15 tys. uchodźców kilka dni na jego opuszczenie ${ }^{6}$. Dla tego niewielkiego liczebnie narodu masowa migracja i rozproszenie na rozległych obszarach imperium groziły asymilacją. Jak twierdzili łotewscy działacze narodowi: „Syberia jest cmentarzem tożsamości narodowej Łotyszy"7. Nawet krótka wizyta w Łotewskim Narodowym Muzeum Sztuki w Rydze, w galerii sztuki XX wieku, ukazuje, jak ważne pozostawało doświadczenie uchodźstwa w łotewskiej pamięci o wojnie. Jest tam bowiem prezentowany szereg obrazów o tej tematyce.

Jeden ze znajdujących się w galerii obrazów przedstawia dwie kobiety siedzące przy stole. Choć zapewne są głodne, to nie mają czego zjeść - jedyny leżący tam talerz jest pusty. Obie kobiety o smutnym wyrazie twarzy zostają ze swym cierpieniem i poczuciem beznadziei same i nie mogą liczyć na pomoc z zewnątrz. Dodatkowo poczucie wyalienowania wzmacniane jest brakiem jakichkolwiek ozdób oraz szarą tonacją całej kompozycji. Autor dzieła, Aleksandrs Drēviņš, sam był uchodźcą wojennym, gdyż od 1915 roku żył i pracował w Moskwie. Mając lewicowe poglądy (brał udział jeszcze w rewolucji 1905-1907), po zakończeniu wojny postanowił zostać w Rosji. Był tam aktywnym członkiem różnych grup artystycznych. Ostatecznie padł ofiarą Wielkiej Czystki w 1938 roku.

\footnotetext{
${ }^{4}$ P. Gatre11, A Whole Empire Walking..., s. 19-20.

${ }^{5}$ M.R. Hatlie, Riga und der Erste Weltkrieg. Eine Exkursion [w:] Über den Weltkrieg hinaus: Kriegserfahrungen in Ostmitteleuropa 1914-1921, Hrsg. J. Ta u ber, Lüneburg 2009, s. 13-33.

${ }^{6}$ P. Gatre11, A Whole Empire Walking..., s. 21.

7 Patrz np. A. Prymaka-On is zk, Bieżeństwo 1915. Zapomniani uchodźcy, Wołowiec 2016, s. 194.
} 


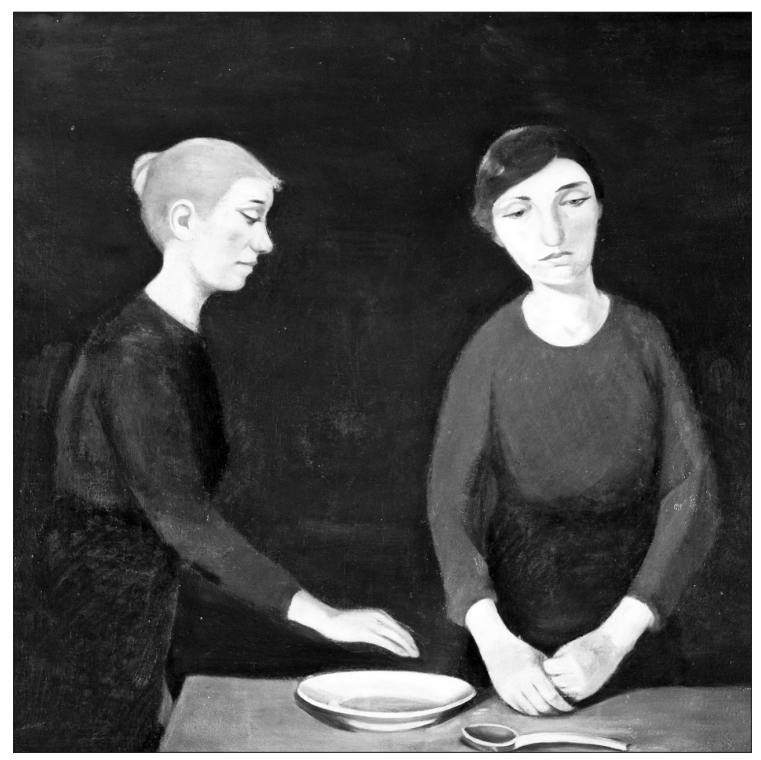

Il. 1. Aleksandrs Drēviņš (1889-1938), Uchodźczynie. Przy stole, 1916, Łotewskie Narodowe Muzeum Sztuki

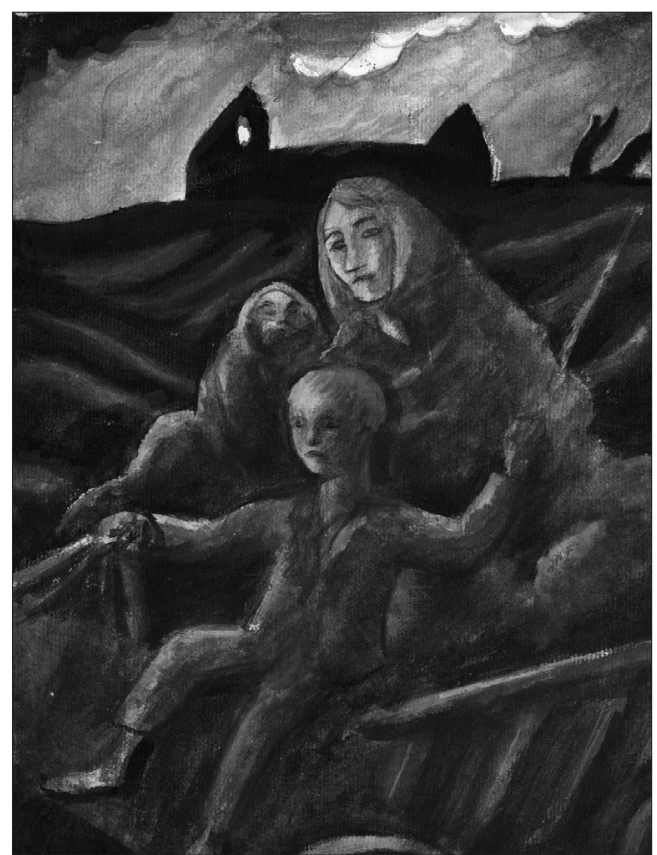

I1. 2. Jāzeps Grosvalds (1891-1920), Uchodźcy. Matka z dzieckiem w wozie, 1915, Łotewskie Narodowe Muzeum Sztuki 
Z płonącej miejscowości uchodzi na wozie matka z dwójką swych dzieci. Pod nieobecność ojca - prawdopodobnie wcielonego do wojska - powozi starszy syn kobiety, który swymi wąttymi rękami stara się zmusić zwierzę pociągowe do jeszcze większego wysiłku. Kobieta z kolei zajmuje się swym młodszym dzieckiem trzymanym na rękach. Wpatrzona $\mathrm{w}$ dal smutnym wzrokiem i pogrążona w myślach stara się umknąć przed zagrożeniem i ochronić swe potomstwo. Uchodźcy nie zabrali zbyt wiele ze swego dobytku. Być może uciekli w ostatnim momencie, do końca łudząc się, że nie będą musieli udawać się w podróż w nieznane. Dramatyzmu scenie dodają materialne zniszczenia widoczne $\mathrm{w}$ tle (ruiny wypalonego domu i ogołocony $\mathrm{z}$ gałęzi pień drzewa). Kobiecie nie zostaje nic innego jak opuścić swój dom i szukać nowego, tymczasowego miejsca dla siebie i swych podopiecznych. W przeciwieństwie do Drēviņša Jāzepsa Grosvaldsa nie dotknęło bolesne doświadczenie uchodźcze. Przyszedł on na świat w rodzinie dobrze sytuowanego i aktywnego społecznie ryskiego prawnika, bogaci i wrażliwi kulturalnie rodzice zapewnili mu wszechstronne wykształcenie. Grosvalds grał na pianinie, znał kilka języków obcych oraz pobierał nauki w prywatnych szkołach artystycznych w Monachium i Paryżu. Po wojnie pracował w łotewskiej ambasadzie w stolicy. Zmarł w 1920 roku na grypę hiszpankę.

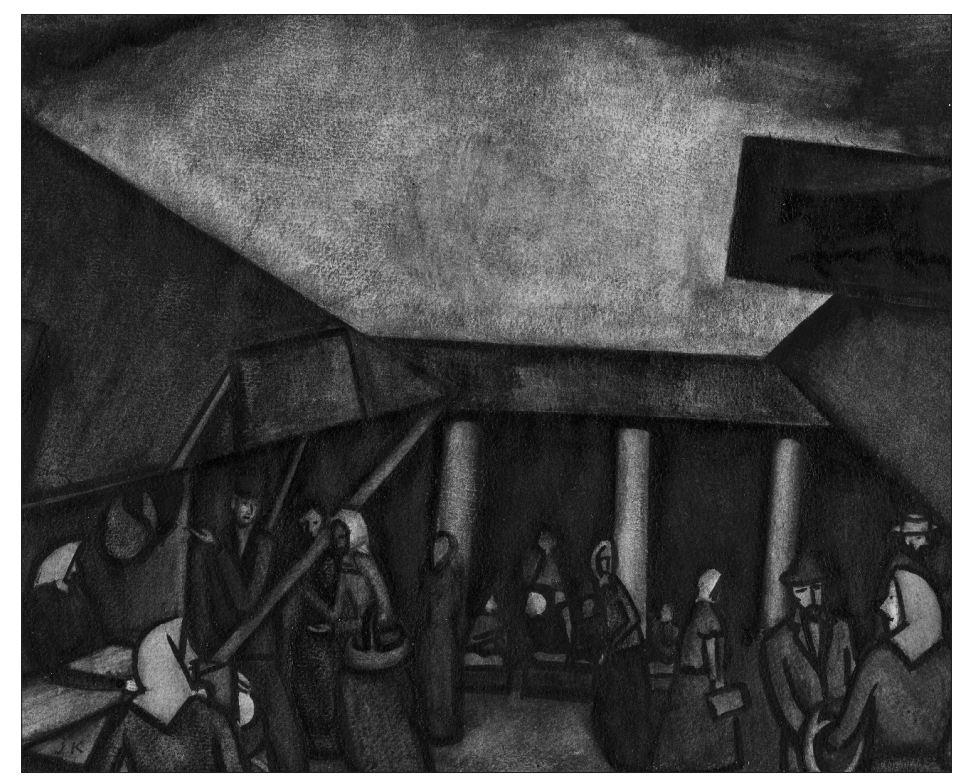

Il. 3. Jēkabs Kazaks (1895-1920), Uchodźcy, 1917, Łotewskie Narodowe Muzeum Sztuki

Na tej niewielkiej akwareli wbrew pozorom także dostrzec można doświadczenie wyalienowania uchodźców. Na pozór w kłębiącym się tłumie trudno mówić o samotności. Jednak osoby na nim przedstawione, głównie kobiety w nakrytych chustami głowach, nie wchodzą ze sobą w bliższe relacje. Stłoczone na niewielkiej przestrzeni, zajmują się same sobą i są pozbawione nawet odrobiny prywatności. Z kolei budynki 
otaczające dziedziniec, na którym koczują uchodźcy, zdają się tworzyć zaporę nie do przebycia. Może to symbolizować wyalienowanie tej grupy spośród miejscowej ludności. Jak wiemy z innych źródeł, uchodźcy wojenni byli przez miejscowych postrzegani jako zagrożenie i konkurenci w dostępie do coraz bardziej deficytowych dóbr, obcy budzący wrogość, a nie współczucie ${ }^{8}$. Ich smutny los zdaje się przypieczętowany zakrytym chmurami stalowym niebem. Autor obrazu - Jēkabs Kazaks, wywodzący się ze skromnej rodziny zamiatacza ulic - podobnie jak Drēviņš z autopsji znał doświadczenie wychodźstwa. W 1915 roku opuścił swą rodzinną Rygę i zamieszkał w Penzie, gdzie kontynuował naukę w miejscowej szkole sztuk pięknych. $\mathrm{Na}$ wychodźstwie nawiązał kontakty z innymi łotewskimi malarzami oraz zapoznał się z rosyjskimi obrazami utrzymanymi w stylistyce modernizmu. Pod wpływem tych inspiracji sam zaczął tworzyć w tej konwencji. Po powrocie na Łotwę zebrał wokół siebie grupę malarzy ekspresjonistów. Zmarł przedwcześnie na gruźlicę w 1920 roku.

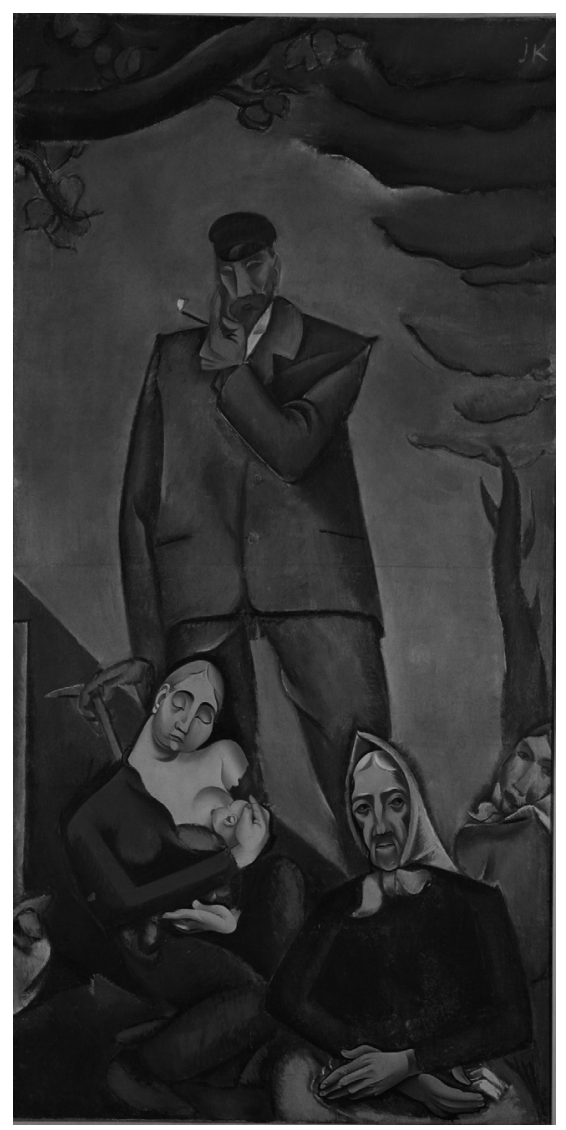

Il. 4. Jēkabs Kazaks (1895-1920), Uchodźcy, 1917, Łotewskie Narodowe Muzeum Sztuki

${ }^{8}$ Ibidem, s. 91ff; 179ff; M. Korzeniow ski, Uchodźcy z Królestwa Polskiego i Galicji w latach Wielkiej Wojny [w:] Studia nad historia społeczna ziem polskich 1914-1918, Warszawa 2018 (Metamorfozy Społeczne, t. 12), s. 224-234; A. Wat s o n, Ring of Steel. Germany and Austria-Hungary in World War I. The People's War, New York 2014, s. 198-206. 
Na obrazie widać przedstawicieli trzech pokoleń Łotyszy, a mianowicie dziadków, matkę i dziecko, którzy pod nieobecność powołanego zapewne do wojska męża i syna stawić muszą czoła nowemu doświadczeniu. Centralną postacią kompozycji jest opierający się na lasce i palący fajkę dziadek, prawdopodobnie nestor rodu. $\mathrm{U}$ jego stóp siedzą trzy kobiety w różnym wieku, z których jedna karmi piersią. Od członków rodziny chłopskiej emanuje spokój i wewnętrzna siła, rzec można gotowość zmierzenia się z trudnym losem, który przypadł im w udziale. Godność sportretowanych osób i ich szlachetna ekspresyjność są podkreślone przez wydłużenie postaci na kształt gotyckich rzeźb. Kolorystyka utrzymana w ciemnej tonacji i zachmurzone niebo pozbawione promieni słonecznych wzmacniają powagę sceny ${ }^{9}$.

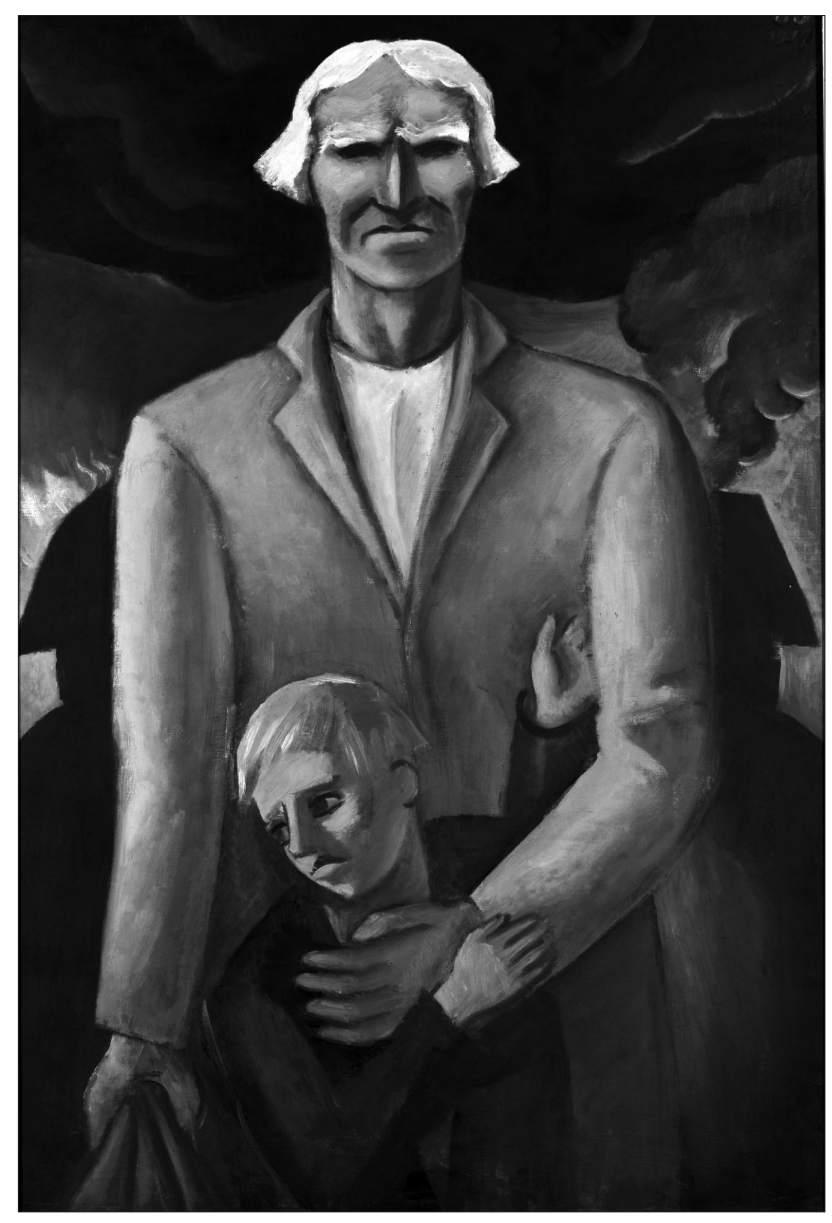

Il. 5. Jāzeps Grosvalds (1891-1920), Uchodźcy (Starzy uchodźcy), 1917, Łotewskie Narodowe Muzeum Sztuki

\footnotetext{
${ }^{9}$ https://kulturaskanons.lv/en/archive/jekabs-kazaks/ [dostęp: 16 IV 2020 r.].
} 
Na pierwszym planie kolejnej kompozycji Jāzepsa Grosvaldsa poświęconej tematyce uchodźczej widać dwie męskie postacie, zapewne dziadka i wnuka. Ten drugi stara się schronić się pod ramieniem dziadka przed niebezpieczeństwami, jakie niesie wojna; wpatrzony jest najwyraźniej w nowe, nieznane widzowi źródło zagrożenia. Dziadek, choć obejmuje wnuka ręką, starając się dać mu pozory bezpieczeństwa, wydaje się równie bezbronny jak on. Patrzy w dal, w prawej ręce trzymając worek. Można domniemywać, że to cały majątek, jaki udało mu się wynieść z palącego się w tle domu. Gęste dymy pożaru spowijają niebo, odbierając tym samym nadzieję na szybką poprawę losu i możliwość odbudowy normalnej egzystencji.

\section{PRZYPADEK POLSKI}

Ziemie polskie od pierwszych dni wojny stały się teatrem działań wojennych z wszelkimi tego dramatycznymi konsekwencjami dla ludności cywilnej. Już na początku sierpnia w głąb kraju ruszyli uchodźcy z terenów przygranicznych, zwłaszcza Kalisza, który wojska niemieckie postanowiły ukarać za rzekome ostrzelanie wojsk okupacyjnych przez ludność cywilną ${ }^{10}$. Sama wojna miała, według rosyjskiej propagandy, ale i wielu działaczy endeckich i konserwatywnych zaboru rosyjskiego, doprowadzić do zbliżenia i pojednania obu narodów słowiańskich. Miała temu służyć także pomoc materialna świadczona między innymi uchodźcom z terenu Królestwa Polskiego.

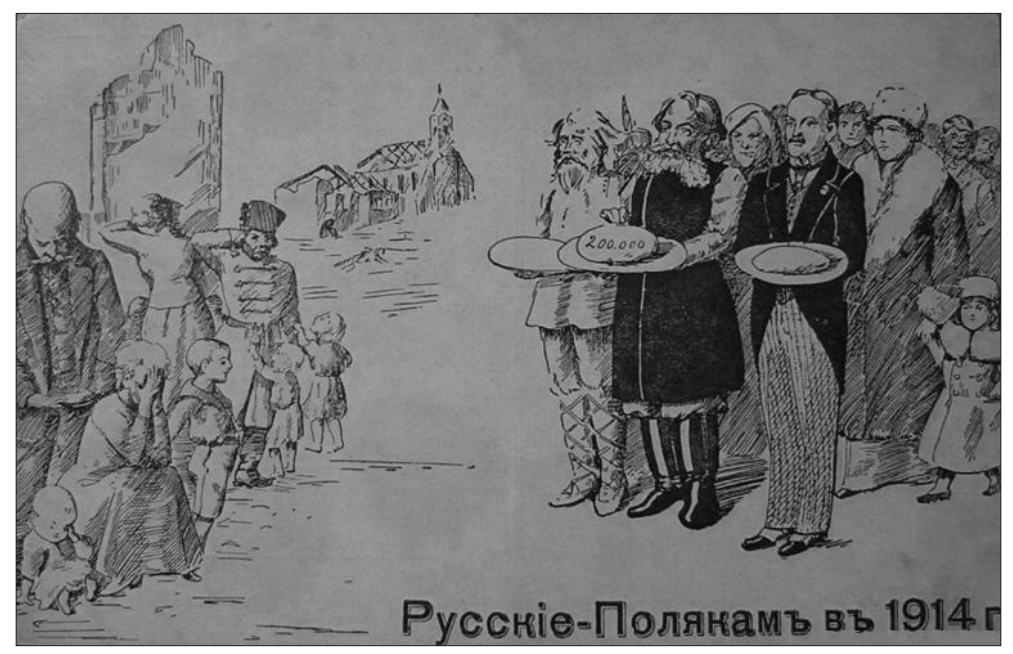

Il. 6. Pocztówka „Rosjanie Polakom”, 1914, zbiory własne autora

${ }^{10}$ Szerzej zob.: M.A. Woźniak, Kalisz. Pogrom miasta 1914, Kalisz 1995; L. En ge 1s te in, A Belgium of Our Own: The Sack of Russian Kalisz, August 1914, „Kritika. Explorations in Russian and Eurasian History" 2009, vol. 10, no. 3, s. 441-473. 
Po lewej stronie kompozycji widać zmartwionych Polaków (płaczące kobiety, bezradne dzieci, strapionych mężczyzn) na tle zniszczonych budynków, w tym kościoła. Nieszczęsnym z pomocą spieszą przedstawiciele różnych klas rosyjskiego społeczeństwa, których można odróżnić po strojach. To bolesne doświadczenie niesie z sobą zatem pewną nadzieję na przyszłość.

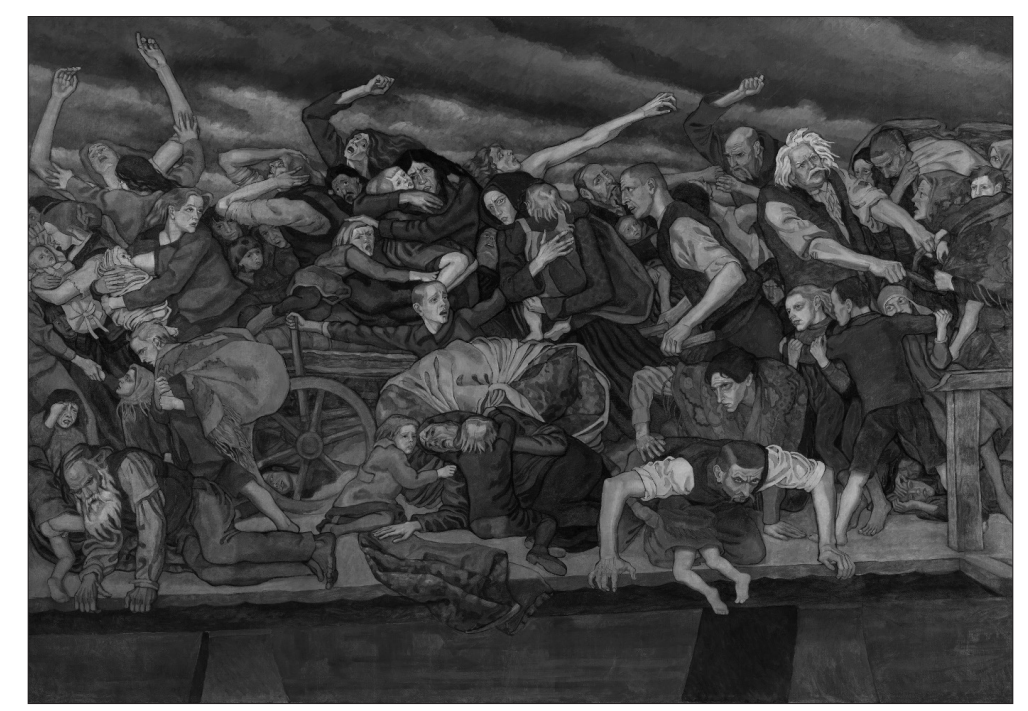

Il. 7. Jan Rembowski (1879-1923), Uchodźcy, ok. 1915, Muzeum Narodowe w Warszawie

Ten monumentalny, utrzymany w apokaliptycznej atmosferze i biblijnej stylizacji obraz przedstawia oszalały tłum kłębiący się na wąskim moście. Z twarzy postaci da się odczytać różne emocje, ale dominują rozpacz i przerażenie uchodźców uciekających w panice przed bliskim i bezpośrednim niebezpieczeństwem. Wzmacnia to mowa ciała - wygięte ciała, poskręcane sylwetki i powyciągane ręce. Gnani są dzikim przestrachem. Kobiety dźwigają niemowlęta i toboły, a u ich spódnic wiszą płaczące dzieci. Nieliczni mężczyźni ciągną lub pchają wózki z dobytkiem. Część uciekinierów już zrezygnowała $\mathrm{z}$ walki i gotowa jest pogodzić się z nieuniknionym losem. Kobieta upada pod ciężarem bagażu niesionego na plecach. Dwie dziewczynki starają się pomóc jej wstać, ale w rzeczywistości tulą się bezradne do swej matki. Obok bosy i brodaty mężczyzna trzymający się krawędzi mostu zdaje się pogodzony $\mathrm{z}$ nadchodzącą śmiercią. Po drugiej stronie z zawiniątka na piersi mężczyzny wysuwa się w otchłań dziecko. Zerwana barierka świadczy dobitnie o tym, że płynąca poniżej rzeka pochłonęła już wiele niewinnych ofiar. Inni, gnani zwierzęcym strachem, są zdeterminowani do dalszej walki o przetrwanie, o czym świadczą wzrok wzbity w dal czy zaciśnięta pięść jednej z postaci - być może w celu zadania ciosu przeszkodzie na drodze do ocalenia. Cała grupa idzie pod wiatr, który można interpretować jako symbol przeciwności losu. Wędrówce potępieńców towarzyszą zapewne wrzaski 
i lamenty. Scenę zamyka zasnute niebo. Nie sposób jednoznacznie wyrokować, czy są to gęste chmury, czy też dym z płonących zabudowań. Wyciągnięte w górę, bezradne ręce zdają się przeklinać tych, którzy tym nieszczęśnikom zgotowali taki los. Rembowski w pierwszym okresie Wielkiej Wojny przebywał na obszarze zaboru austriackiego, gdzie między innymi portretował legionistów. W Warszawie osiadł dopiero za niemieckiej okupacji w 1916 roku. Podczas pierwszej wojny światowej jego dzieła prezentowano na wystawach między innymi w Krakowie $(1916,1917)$, Zakopanem (1916) i we Lwowie (1918) ${ }^{11}$.

\section{PRZYPADEK ŻYDOWSKICH UCHODŹCÓW W ROSJI}

Wśród uchodźców wojennych na terenie Rosji niemałą grupę stanowili Żydzi. Ich specyficzne doświadczenie uwiecznił w cyklu grafik zatytułowanych Dzban łez lub Na rozkaz cara rosyjski Żyd Abel Pann (1883-1963). Na 24 grafikach zaprezentował on los Żydów rosyjskich podczas wojny, w tym doświadczenie uchodźców i wypędzonych. Abba Pfefferman, bo tak pierwotnie nazywał się artysta, urodził się na Łotwie, a nauki rysunku pobierał między innymi w Witebsku (u nauczyciela Marka Chagalla) i w odeskiej Szkole Sztuk Pięknych. W 1903 roku wyjechał na studia do Paryża, by po 10 latach osiąść na stałe w Palestynie.

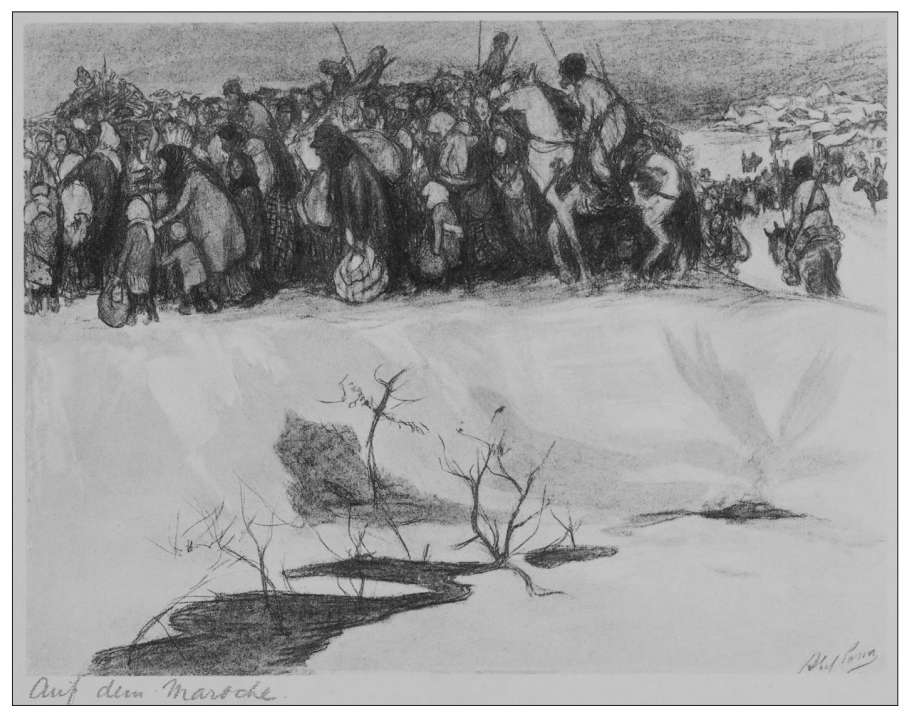

Il. 8. Abel Pann (1883-1963), W marszu, Żydowski Instytut Historyczny im. E. Ringelbluma w Warszawie

${ }^{11}$ Ł. Mieszkowski, Liście, nie ludzie [w:] Krzyczac: Polska! Niepodległa 1918. Przewodnik po wystawie, red. H. Haintze, M. Pi k kut ow a, Warszawa 2018, s. 156-159; https://culture.pl/pl/tworca/ jan-rembowski [dostęp: 16 IX 2020 r.]. 
Grafika najprawdopodobniej prezentuje wymarsz wypędzonych i eskortowanych przez wojsko mieszkańców sztetla. Pieszemu exodusowi, głównie kobiet i dzieci objuczonych ciężkimi pakunkami, nie sprzyjają ani zimowa pogoda, ani państwo, które traktuje ofiary wojny jak potencjalnych przestępców. Towarzyszące wojsko, zamiast pomagać wypędzanym, pilnuje tłumu i popędza go. Stłoczeni wychodźcy zdają się akceptować swój los i bez oporu, który i tak byłby bezskuteczny, podążają w kierunku wskazanym przez władze.

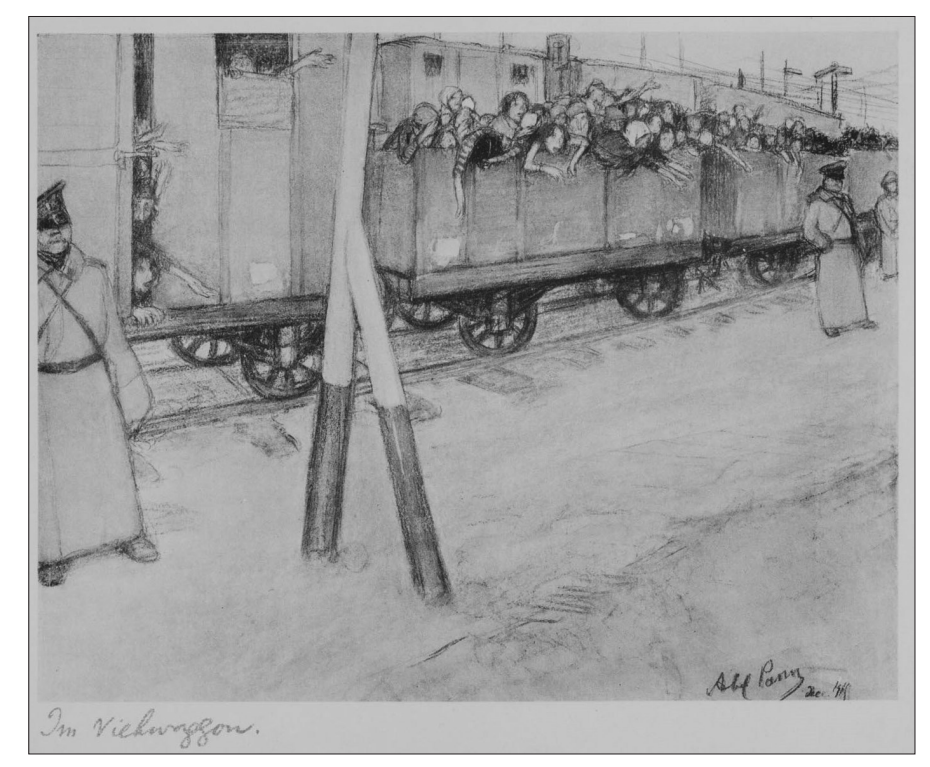

Il. 9. Abel Pann (1883-1963), W bydlęcym wagonie, Żydowski Instytut Historyczny im. E. Ringelbluma w Warszawie

W tytułowym bydlęcym wagonie, który zatrzymał się na stacji w drodze w nieznane i jest pilnowany przez rosyjskie wojsko, stłoczone są dzieci. Wagony są dosłownie napchane uchodźcami. Gestykulacją i prawdopodobnie krzykami starają się zwrócić uwagę na swoje potrzeby. Spotyka ich jedynie obojętność i bezduszność odwróconych do nich tyłem wojskowych. Nie są oni skłonni ulżyć w nieszczęściu podróżującym w nieznane dzieciom pozbawionym opieki rodziców. Mają zapobiec najwyraźniej niepożądanym z punktu widzenia władz - kontaktom uchodźców z ludnością miejscową. Zresztą nikt $\mathrm{z}$ miejscowych nie spieszy im na pomoc, więc i straż wydaje się zbyteczna.

Co warto podkreślić, w przypadku uchodźców żydowskich już od pierwszych dni wojny byli oni na różne sposoby szykanowani przez wojska rosyjskie hołdujące 
antysemickim uprzedzeniom i stereotypom ${ }^{12}$. W tym przypadku byli oni wewnętrznymi uchodźcami zmuszonymi przez oddziały własnego państwa do opuszczenia swych domostw. Taki ich obraz utrwalił także Pann. Wieści o takim traktowaniu Żydów przez wojska carskie musiały różnymi kanałami - zapewne głównie prywatnymi listami - trafić poza granice Rosji. Z pewnością na ich upowszechnianiu nie zależało władzom sojuszniczej Francji. Ze względu na antyrosyjską wymowę, a co za tym idzie - protesty rosyjskiego ambasadora w Paryżu cykl grafik nie mógł być wystawiany publicznie we Francji, zyskał jednak bardzo dużą popularność w Stanach Zjednoczonych. Obrona posłużyła się nimi jako dowodem podczas procesu Szolema Szwarcbarda, zabójcy Semana Petlury, który odbył się w październiku 1927 roku ${ }^{13}$. Podczas I wojny światowej Pann nie przebywał w Rosji i nie utrwalał na grafikach wydarzeń z tamtego czasu. Do zajęcia się tematem losu żydowskich uchodźców, poza pochodzeniem i syjonistycznymi przekonaniami, skłoniło go jednak także osobiste doświadczenie. W 1903 roku Pann był bowiem świadkiem pogromu w Kiszyniowie, którego sceny również utrwalił w swych grafikach. Od tamtej pory uznał za swą misję życiową pełnienie funkcji malarskiego kronikarza losów narodu żydowskiego. Temu wyborowi pozostał wierny do końca swych dni.

\section{Podsumowanie}

Z pewnością wybór zaprezentowanej tu ikonografii nie jest reprezentatywny i nie rości sobie pretensji do całościowego opisu zjawiska. Sądzę jednak, że udało mi się wyodrębnić oraz przedstawić główne toposy i motywy związane z doświadczeniem migracji doby Wielkiej Wojny. We wszystkich prezentowanych ujęciach ikonograficznych uchodźcy są bezbronnymi, niewinnymi ofiarami ponoszącymi dramatyczne konsekwencje wojny, za którą żaden z nich nie ponosi odpowiedzialności. Na różne sposoby artyści oddają w swych dziełach takie problemy, jak: niepewność jutra, głód, choroby, śmierć, poczucie straty stron ojczystych, zagrożenie, tęsknota, wyobcowanie, beznadzieja, bezradność, przymusowe bezrobocie, brak zajęcia i środków do życia, zagubienie w nieznanym świecie czy utrata własnej godności. To doświadczenie było głównie udziałem osób najbardziej bezradnych wobec zaistniałej sytuacji, a mianowicie kobiet, dzieci oraz osób starszych.

Wydaje się, że tematykę uchodźstwa wojennego podejmowali malarze czy graficy samoczynnie, motywowani dążeniem albo do utrwalenia własnych bolesnych doświadczeń, albo cierpień grupy, z którą się identyfikowali. Rembowski i Grosvalds, którzy osobiście nie doświadczyli uchodźstwa, a podczas wojny malowali m.in.

12 Szerzej zob.: A.V. Prus in, Nationalizing a Borderland: War, Ethnicity, and Anti-Jewish Violence in East Galicia, 1914-1920, Tuscaloosa 2005, s. 15-23; F.H. Schuster, Zwischen allen Fronten. Osteuropäische Juden während des Ersten Weltkrieges (1914-1919), Köln 2004, s. 233; S. An-Ski, Tragedia Żydów galicyjskich w czasie I wojny światowej. Wrażenia i refleksje z podróży po kraju, thum. K.D. Maju s, wyd. K.D. Maju s, S. Stępi eń, Przemyśl 2010.

${ }^{13}$ K. Szymaniak, (Nie) na wlasne oczy. Demony wojny i pogromu Abla Panna [w:] Krzyczac: Polska!, s. 138-141. 
żołnierzy polskich i łotewskich formacji niepodległościowych, w swej twórczości także zajęli się uchodźcami. Najwyraźniej uznali, że to temat ważny dla ich narodów, a z tego względu wymagający uwiecznienia na płótnie. Podobnie rzecz się ma z Pannem, dla którego niedola uchodźców żydowskich z lat Wielkiej Wojny była kolejnym etapem w niekończącym się łańcuchu prześladowań Żydów w carskiej Rosji. Wątek uchodźczy pojawiał się także w oficjalnej propagandzie wojennej (czego dowodem jest ilustracja z rosyjskiej pocztówki), lecz głównie w formie zdjęć w prasie i okolicznościowych publikacjach. To jednak temat na oddzielny artykuł.

\section{BIBLIOGRAFIA}

An-Ski S., Tragedia Żydów galicyjskich w czasie I wojny światowej. Wrażenia i refleksje z podróży po kraju, tłum. K.D. Maju s, wyd. K.D. Maju s, S. S tę pi eń, Przemyśl 2010. Bildpropaganda im Ersten Weltkrieg, Hrsg. R. Zühlke, Hamburg 2000.

Engels te in L., A Belgium of Our Own: The Sack of Russian Kalisz, August 1914, „Kritika. Explorations in Russian and Eurasian History" 2009, vol. 10, no. 3, s. 441-473.

Gatrell P., A Whole Empire Walking: Refugees in Russia during World War I, Bloomington 2011.

Gatrell P., Refugees [w:] 1914-1918-online: International Encyclopedia of the First World War, eds. U. Danie1, P. Gatre11, O. Janz, H. Jones, J. Ke en e, A. Kramer, B. N a s s o n, Berlin 2014, http:/www.1914-1918-online.net/ [dostęp: 16 IV 2020 r.].

Hatlie M.R., Riga und der Erste Weltkrieg. Eine Exkursion [w:] Über den Weltkrieg hinaus: Kriegserfahrungen in Ostmitteleuropa 1914-1921, Hrsg. J. Ta u b e r, Lüneburg 2009, s. 13-33.

Jaw orski R., Mutter - Liebchen - Heroinen. Propagandapostkarten aus den Ersten Weltkrieg, Köln-Weimar-Wien 2015.

Korzeniowski M., Mądzik M., Tarasiuk D., Tułaczy los. Uchodźcy polscy w imperium rosyjskim w latach pierwszej wojny światowej, Lublin 2007.

Korzeniowski M., Uchodźcy z Królestwa Polskiego i Galicji w latach Wielkiej Wojny [w:] Studia nad historia społeczna ziem polskich 1914-1918, Warszawa 2018 (Metamorfozy Społeczne, t. 12), s. 203-239.

Kwestia polska $w$ propagandzie $w$ okresie pierwszej wojny światowej, red. W. Molik, T. Schramm, D. Szymczak, Poznań 2018.

Mieszkowski Ł., Liście, nie ludzie [w:] Krzyczac: Polska! Niepodległa 1918. Przewodnik po wystawie, red. H. Haintze, M. P i e kut ow a, Warszawa 2018, s. 156-159.

Peeling S., Refugees (Russian Empire) [w:] 1914-1918-online: International Encyclopedia of the First World War, eds. U. Dani el, P. Gatrel1, O. Janz, H. Jon e s, J. Ke en e, A. Kramer, B. Nasson, Berlin 2014, http://www.1914-1918-online.net/ [dostęp: 16 IV 2020 r.].

Prusin A.V., Nationalizing a Borderland: War, Ethnicity, and Anti-Jewish Violence in East Galicia, 1914-1920, Tuscaloosa 2005.

Prymaka-Onis zk A., Bieżeństwo 1915. Zapomniani uchodźcy, Wołowiec 2016.

Shuster F.H., Zwischen allen Fronten. Osteuropäische Juden während des Ersten Weltkrieges (1914-1919), Köln 2004.

S zy m a n i k K., (Nie) na własne oczy. Demony wojny i pogromu Abla Panna [w:] Krzyczac: Polska! Niepodległa 1918. Przewodnik po wystawie, red. H. Haintze, M. P i ekut ow a, Warszawa 2018, s. 138-141. 
Wat s on A., Ring of Steel: Germany and Austria-Hungary in World War I. The People's War, New York 2014.

Woźniak M.A., Kalisz. Pogrom miasta 1914, Kalisz 1995.

https://culture.pl/pl/tworca/jan-rembowski [dostęp: 16 IX 2020 r.].

https://kulturaskanons.lv/en/archive/jekabs-kazaks/ [dostęp: 16 IV 2020 r.]. 